DOI: $10.29303 /$ jrpb.v8i1.156

ISSN 2301-8119, e-ISSN 2443-1354

Tersedia online di http://jrpb.unram.ac.id/

\title{
PENENTUAN LAJU DEOKSIGENASI DAN REOKSIGENASI SUNGAI MAYANG SEGMEN DESA GARAHAN KRAJAN SAMPAI DESA SUMBERJATI, KECAMATAN SILO, KABUPATEN JEMBER MENGGUNAKAN PERSAMAAN STREETER-PHELPS
}

\author{
Determination of Deoxygenation and Reoxygenation Rate of Mayang River \\ in Garahan Krajan Village until Sumberjati Village, Silo Sub District, Jember Regency \\ using the Streeter-Phelps Equation
}

\section{Sri Wahyuningsih, Elida Novita, Mardhatillah Arum Annisa*)}

Teknik Pertanian, Fakultas Teknologi Pertanian, Universitas Jember J1. Kalimantan No. 37, Jember 68121, Indonesia

Email $^{*}$ : mardhatillaharumannisa@gmail.com

Diterima: Desember 2019

Disetujui: Februari 2020

\begin{abstract}
Mayang River is the longest river in Jember Regency. Mayang River which segment Garahan Krajan Village to Sumberjati Village is an upstream river located close to the mountains. The people around there use the river to fulfill their daily needs and agricultural irrigation. Organic pollutants from domestic waste and agricultural waste that enter the river can reduce the concentration of dissolved oxygen (DO) in the river which can affect river water quality. Mayang River's water was sampled at four monitoring points, they were MYG01, MYG02, MYG03, and MYG04 used the purposive sampling method, then water quality analysis was carried out. Determination of the carrying capacity is done using the Streeter Phelps method which aims to determine the rate of deoxygenation and reoxygenation so that it can carry out natural purification. The purpose of this study is to determine the rate of deoxygenation and reoxygenation rate using the Streeter-Phelps method. Deoxygenation rate and reoxygenation rate affect changed in the concentration of dissolved oxygen in the waters. This study used primary data by taking river water samples by grab sampling at 4 monitoring points. The results of the Mayang River study in the Garahan Krajan Village to Sumberjati Village segments had an average $\mathrm{rD}$ of $0.002 \mathrm{mg} / \mathrm{l}$. day and an RR of $5.49 \mathrm{mg} / \mathrm{l}$. day. The rD value was smaller than the $r R$ value which indicate that the addition of dissolved oxygen was greater than the reduction of dissolved oxygen in the waters so that the natural purification of the river can take place properly. Analysis of river water quality showed that the river is still above the threshold quality standard of class II river water so that the quality of river water is still good and safe for use by the community. Furthermore, the results of this study will be useful for determining the carrying capacity of rivers.
\end{abstract}

Keywords: deoxygenation rate, reoxygenation rate, Streeter-Phelps, Mayang river 


\begin{abstract}
ABSTRAK
Sungai Mayang merupakan sungai terpanjang di Kabupaten Jember. Sungai Mayang Segmen Desa Garahan Krajan sampai Desa Sumberjati merupakan sungai bagian hulu yang berlokasi dekat dengan pegunungan. Masyarakat sekitar memanfaatkan sungai tersebut untuk memenuhi kebutuhan sehari-hari dan irigasi pertanian. Bahan pencemar organik dari limbah domestik dan limbah pertanian yang masuk ke sungai dapat menurunkan konsentrasi oksigen terlarut (DO) di sungai yang dapat mempengaruhi kualitas air sungai. Pengambilan sampel air Sungai Mayang berada di empat titik pantau, yaitu MYG01, MYG02, MYG03, dan MYG04 yang menggunakan metode purposive sampling method, kemudian dilakukan analisis kualitas air. Penentuan daya tampung dilakukan dengan menggunakan metode Streeter-Phelps yang bertujuan untuk mengetahui laju deoksigenasi dan laju reaerasi sungai sehingga mampu untuk melakukan purifikasi alami. Tujuan penelitian ini adalah untuk mengetahui laju deoksigenasi dan laju reoksigenasi menggunakan metode Streeter-Phelps. Laju deoksigenasi dan laju reoksigenasi tersebut mempengaruhi perubahan konsentrasi oksigen terlarut pada perairan. Penelitian ini menggunakan data primer dengan mengambil sampel air sungai secara grab sampling pada 4 titik pemantauan. Hasil penelitian Sungai Mayang segmen Desa Garahan Krajan sampai Desa Sumberjati memiliki rata-rata rD sebesar 0,002 mg/l.hari dan rR sebesar $5,49 \mathrm{mg} / \mathrm{l}$.hari. Nilai rD yang lebih kecil dari nilai rR menunjukkan bahwa penambahan oksigen terlarut lebih besar dibandingkan pengurangan oksigen terlarut di dalam perairan sehingga purifikasi alami sungai dapat berlangsung dengan baik. Analisis kualitas air sungai menunjukkan bahwa sungai masih berada di atas ambang batas baku mutu kualitas air sungai kelas II sehingga kualitas air sungai masih bagus dan aman digunakan oleh masyarakat. Selanjutnya hasil penelitian ini akan bermanfaat bagi penentuan daya dukung sungai.
\end{abstract}

Kata kunci: laju deoksigenasi, laju reoksigenasi, Streeter-Phelps, sungai Mayang

\section{PENDAHULUAN}

\section{Latar Belakang}

Daerah Aliran Sungai (DAS) merupakan daerah dimana air hujan yang jatuh di daerah yang dibatasi oleh pegunungan mengalir menuju satu titik, yaitu sungai utama (Triatmodjo, 2013). Pengelolaan DAS berkelanjutan sangat penting karena berhubungan dengan banyak aspek antropogenik penggunaan sumber daya alam. DAS kritis dapat disebabkan akibat pengelolaan DAS yang dilakukan secara tidak tepat. Kekritisan DAS dapat dilihat dari beberapa indikator, salah satunya adalah kualitas air. Beberapa parameter yang dianggap penting sebagai parameter kunci yang menggambarkan kualitas perairan sungai Wanggu, yaitu: (1) parameter fisik (suhu, kekeruhan, TSS, kecepatan arus); (2) parameter kimia ( $\mathrm{pH}$, COD, BOD, DO); dan (3) parameter biologi (makroinvertebrata) (Kahirun, dkk., 2019).
Dengan menurunkan beban pencemar yang masuk ke dalam badan air, kekritisan kualitas air diharapkan dapat ditekan.

Salah satu DAS di Kabupaten Jember adalah DAS Antirogo. Pada DAS Antirogo terdapat Sungai Mayang yang merupakan sungai terpanjang di Kabupaten Jember dengan panjang $145.500 \mathrm{~m}$ dan mampu mengairi lahan seluas 5.860 ha (Percepatan Pembangunan Sanitasi Pemukiman, 2012). Di sepanjang Sungai Mayang terdapat berbagai aktivitas manusia seperti kegiatan industri, rumah tangga (MCK), dan irigasi pertanian. Limbah hasil kegiatan-kegiatan tersebut dibuang langsung ke badan sungai dan berpotensi meningkatkan pencemaran air seperti menurunnya kualitas air. Kualitas air sungai Mayang mengalami penurunan akibat pencemaran. Hal ini mengacu pada Peraturan Pemerintah Nomor 82 Tahun 2011 tentang Pengolahan Kualitas Air dan Pengendalian Pencemaran Air, dimana Sungai Mayang tidak memenuhi kriteria 
mutu air kelas II untuk parameter BOD, COD, DO, dan total fosfat (Dinas Kebersihan dan Lingkungan Hidup Kabupaten Jember, 2007). Oleh karena itu, perlu dilakukan penentuan daya tampung sungai untuk mengetahui kemampuan sungai dalam menerima beban pencemaran yang dapat dilakukan dengan pemodelan kualitas air. Menurut Keputusan Menteri Negara Lingkungan Hidup Nomor 110 tentang pedoman penetapan daya tampung beban pencemaran air pada sumber air (2003), metode yang digunakan dalam pemodelan kualitas air adalah Metode Streeter-Phelps. Metode Streeter-Phelps dipengaruhi oleh dua fenomena yaitu proses pengurangan oksigen terlarut (deoksigenasi) akibat aktivitas bakteri dalam menguraikan bahan organik dalam air (dekomposisi bahan organik) serta proses peningkatan oksigen terlarut (reoksigenasi) yang disebabkan oleh tubulensi aliran sungai (Arbie, dkk., 2015).

Penggunaan motode Streeter-Phelps akan menunjukkan kemampuan sungai untuk melakukan purifikasi alami yang dipengaruhi oleh laju deoksigenasi dan laju reoksigenasi. Dengan demikian, perlu dilakukan analisis laju deoksigenasi dan reoksigenasi Sungai Mayang Segmen Desa Garahan Krajan Sampai Desa Sumberjati, Kecamatan Silo, Kabupaten Jember guna mengetahui kemampuan sungai untuk melakukan purifikasi alami.

\section{Tujuan}

Tujuan dari penelitian ini adalah menentukan laju deoksigenasi dan laju reoksigenasi Sungai Mayang Segmen Desa Garahan Krajan sampai Desa Sumberjati Kecamatan Silo Kabupaten Jember.

\section{METODE PENELITIAN}

\section{Alat dan Bahan}

Alat yang digunakan meliputi GPS, pasak, roll meter, tali tampar, Seba Hydrometrie F1 Universal Current Meter, termometer, botol sampel, cool box, kamera digital, botol winkler $250 \mathrm{ml}$ dan $150 \mathrm{ml}$, erlenmeyer, satu set vacuum pump, pipet volumetrik $100 \mathrm{ml}$, pipet suntik $1 \mathrm{ml}$, buret $25 \mathrm{ml}$, bola penghisap, corong, desikator, oven, cawan porselen, cawan alumunnium, timbangan digital, $\mathrm{pH}$ meter, dan Oakton WD-35635-00 T-100 Turbidity Meter Kit with Calibration Vials. Bahan yang digunakan meliputi sampel air Sungai Mayang, larutan $\mathrm{MnSO}_{4}$, larutan Alkaliiodida Azida, larutan $\mathrm{H}_{2} \mathrm{SO}_{4}$, larutan Amilum, larutan $\mathrm{Na}_{2} \mathrm{~S}_{2} \mathrm{O}_{3} 0,025 \mathrm{~N}$, kertas saring diameter $0,45 \mu \mathrm{m}$, dan Aquades.

\section{Pengujian Kualitas Air}

Analisis kualitas air digunakan untuk mengetahui kelas air sebagai tolak ukur mutu air berdasarkan Permen RI Nomor 82 tahun 2001 dengan parameter DO dan BOD. Analisa DO dilakukan dengan titrasi winkler dan analisa $\mathrm{BOD}_{5}$ dilakukan pada temperatur inkubasi $20^{\circ} \mathrm{C}$ selama lima hari. Pengambilan data kualitas air per parameter dilakukan sebanyak 3 kali dengan selisih satu hari untuk setiap pengambilan. Sedangkan, pengambilan sampel air dari sungai dengan metode Grab Sampling menggunakan botol sampel dan diawetkan dengan menempatkannya pada cool box. Kemudian, dilakukan analisis parameter kualitas di Laboratorium Teknik Pengendalian dan Konservasi Lingkungan Jurusan Teknik Pertanian, Fakultas Teknologi Pertanian, Universitas Jember.

Penelitian dilakukan di empat titik lokasi yaitu MYG01, MYG02, MYG03, dan MYG04. Titik pengujian ditentukan mengacu pada metode standar penentuan titik pengukuran debit aliran sungai dan pengambilan uji air sungai dan berdasarkan pertimbangan akses menuju lokasi serta keadaan lokasi penelitian. Titik pengujian ditentukan dengan mencari lokasi yang distribusi alirannya merata dan tidak ada aliran yang memutar. Menurut Standar Nasional Indonesia 6989.57 tahun 2008 tentang metoda pengambilan contoh air permukaan, titik pengukuran debit yang digunakan sebagai titik pengambilan contoh uji harus berada pada lokasi setelah menerima zat pencemar (minimal $200 \mathrm{~m}$ ) 


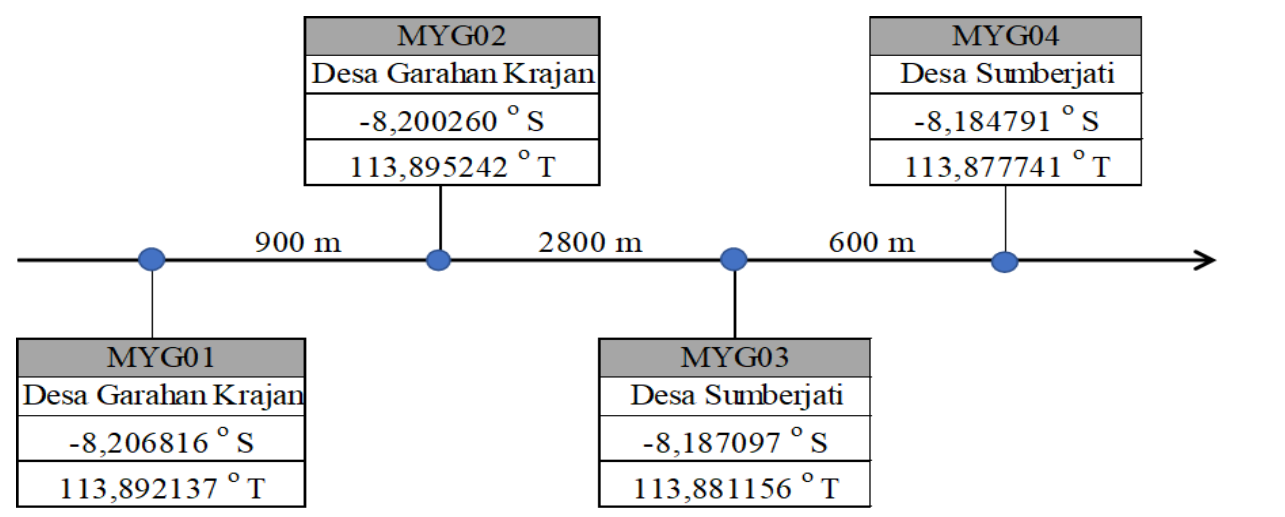

Gambar 1. Pembagian Titik Lokasi Penelitian

sehingga zat pencemar yang masuk dapat tercampur secara maksimal. Pembagian titik pengukuran disajikan pada Gambar 1.

\section{Pengukuran Karakteristik Sungai}

Pengukuran karakteristik sungai meliputi pengukuran dimensi sungai, pengukuran kecepatan aliran sungai, dan pengukuran debit aliran sungai. Pengukuran dimensi sungai dilakukan dengan membagi lebar sungai menjadi 10 pias dan lebar pias tersebut memiliki interval jarak yang sama. Kemudian, dilakukan pengukuran kedalaman sungai sehingga didapatkan luas penampang (A) atau cross section dari hasil pengukuran kedalaman $(\mathrm{H})$ dan lebar $(\mathrm{L})$ sungai yang dilakukan menggunakan tongkat, tali tampar, dan roll meter.

Pengambilan data kecepatan aliran dan debit dilakukan sebanyak 3 kali dengan selisih satu hariuntuk setiap pengambilan. Pengukuran kecepatan (V) aliran sungai menggunakan current meter dilakukan pada masing-masing pias dan menghasilkan data berupa jumlah putaran baling-baling per satuan waktu. Langkah-langkah pengukuran kecepatan aliran yang dilakukan sebagaimana telah ditetapkan dalam SNI 8066:2015 dengan range waktu yang ditentukan, yaitu 10 detik. Data hasil pengukuran cross section Sungai Mayang disajikan pada Gambar 2.

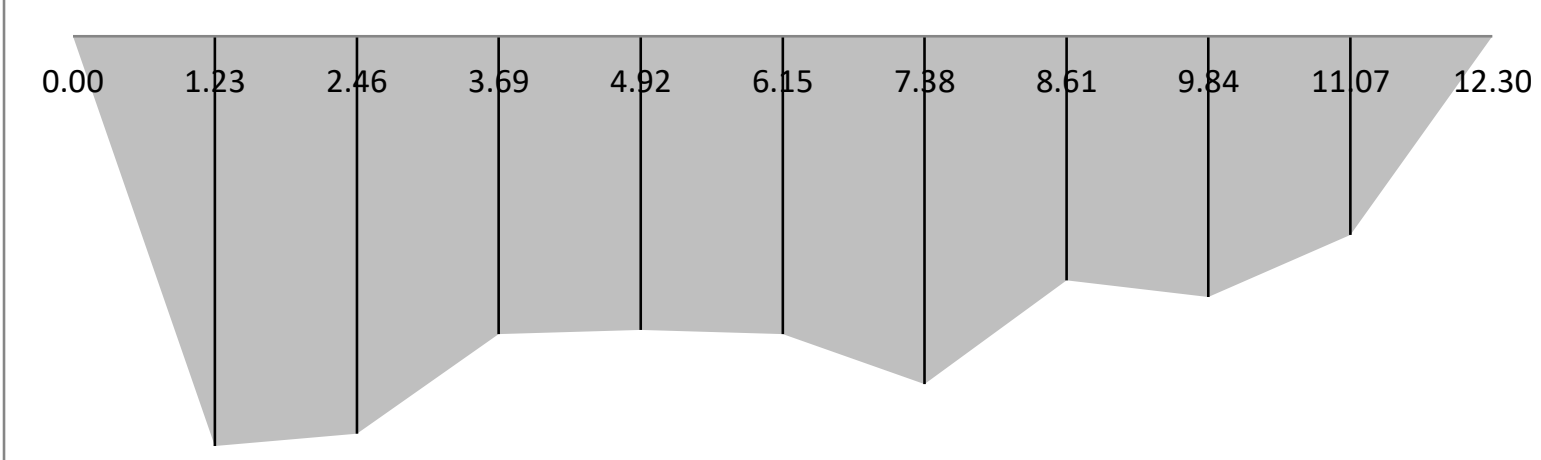

Gambar 2. Data cross section Sungai Mayang Titik MYG01

Perhitungan kecepatan aliran disesuaikan dengan current meter menggunakan Persamaan 1 (Triatmodjo, 2013).

$\mathrm{V}=\mathrm{a}+\mathrm{b} \mathrm{n}$
Keterangan:

$\mathrm{V}=$ kecepatan aliran air ( $\mathrm{m} /$ detik)

$\mathrm{a}=$ konstanta current meter menurut tipe alat

$\mathrm{n}=$ jumlah putaran baling-baling (putaran/detik) 
Tabel 1. Penentuan Kedalaman dan Perhitungan Kecepatan Aliran

\begin{tabular}{cll}
\hline $\begin{array}{c}\text { Kedalaman air } \\
(\mathrm{d}) \mathrm{m}\end{array}$ & \multicolumn{1}{c}{ Titik Pengukuran } & \multicolumn{1}{c}{ V rata-rata (m/detik) } \\
\hline$<0,6$ & $0,6 \mathrm{~d}$ & $\mathrm{~V}=\mathrm{V}_{0,6}$ \\
$0,6-3$ & $0,2 \mathrm{~d}$ dan $0,8 \mathrm{~d}$ & $\mathrm{~V}=0,5\left(\mathrm{~V}_{0,2}+\mathrm{V}_{0,8}\right)$ \\
$3-6$ & $0,2 \mathrm{~d} ; 0,6 \mathrm{~d} ;$ dan $0,8 \mathrm{~d}$ & $\mathrm{~V}=0,25\left(\mathrm{~V}_{0,2}+\mathrm{V}_{0,6}+\mathrm{V}_{0,8}\right)$ \\
$>6$ & $\mathrm{~S} ; 0.2 \mathrm{~d} ; 0,6 \mathrm{~d} ; 0,8 \mathrm{~d} ;$ dan $\mathrm{B}$ & $\mathrm{V}=0,1\left(\mathrm{VS}+3 \mathrm{~V}_{0,2}+2 \mathrm{~V}_{0,6}+3 \mathrm{~V}_{0,8}+\mathrm{V}_{\mathrm{B}}\right)$ \\
\hline
\end{tabular}

Sumber: Rahayu, dkk., (2009)

Kedalaman pengukuran dan perhitungan kecepatan aliran dapat ditentukan seperti pada Tabel 1. Pengukuran debit (Q) aliran sungai merupakan pengukuran terhadap jumlah air yang mengalir di dalam saluran per unit waktu $\left(\mathrm{m}^{3} /\right.$ detik). Debit aliran sungai pada setiap penampang dapat dihitung dengan Persamaan 2 (Rahayu, dkk., 2009).

$Q=A x V$

Keterangan:

$Q=$ Debit aliran $\left(\mathrm{m}^{3} /\right.$ detik $)$

$A \quad=$ Luas Penampang $\left(\mathrm{m}^{2}\right)$

$V \quad=$ Kecepatan (m/detik)

\section{Metode Streeter-Phelps}

Metode

Streeter-Phelps

mengembangkan perubahan pasokan oksigen terlarut (DO) akibat menerima pencemar organik yang masuk ke badan air sungai. Selain itu, pada pemodelan yang dikembangkan oleh Streeter dan Phelps (1925), perubahan konsentrasi oksigen terlarut pada perairan dipengaruhi oleh proses pengurangan oksigen terlarut (deoksigenasi) akibat aktivitas bakteri dalam menguraikan bahan organik dalam air (dekomposisi bahan organik) serta proses peningkatan oksigen terlarut (reaerasi) yang disebabkan oleh turbulensi aliran sungai (Arbie, dkk., 2015). Perubahan konsentrasi oksigen terlarut tersebut juga dapat digunakan untuk menggambarkan kemampuan purifikasi alami (self purification).

Streeter dan Phepls (1925) menyatakan bahwa laju oksidasi biokimiawi senyawa organik (dL/dt) ditentukan oleh konsentrasi senyawa organik sisa (residual) atau ditunjukkan dengan Persamaan 3. $\frac{d L}{d t}=-K \times L_{0}$

Jika konsentrasi awal senyawa organik sebagai BOD adalah $L_{0}$ yang dinyatakan dalam BOD ultimate (total) dan $L_{t}$ adalah BOD residual pada saat $t(\mathrm{mg} / \mathrm{l})$, maka hasil integrasi pertama selama masa oksidasi disajikan pada Persamaan 4.

$L_{t}=L_{0} \cdot e^{(-K . t)}$

Menurut Metcalf dan Eddy (2004), nilai $L_{0}$ diperoleh dari Persamaan 5.

$$
L_{0}=\frac{B O D_{5}}{\left(1-e^{-K . t}\right)}
$$

Nilai K adalah konstanta dekomposisi bahan organik $\left(\right.$ hari $^{-1}$ ) pada botol BOD dengan inkubasi pada temperatur $20^{\circ} \mathrm{C}$. Nilai $\mathrm{K}$ dapat ditentukan dengan pengamatan BOD selama 10 hari dengan interval waktu pengamatan 2 hari dan menggunakan Persamaan 6 (Metcalf dan Eddy, 2004).

$\mathrm{na}+\mathrm{b} \Sigma \mathrm{y}-\Sigma \mathrm{y}^{\prime}=0$, dan

$\mathrm{a} \Sigma \mathrm{y}+\mathrm{b} \Sigma \mathrm{y}^{2}-\Sigma \mathrm{yy}^{\prime}=0$.

Keterangan:

$$
\begin{array}{ll}
\mathrm{n} & =\text { jumlah data contoh uji } \\
\mathrm{y}, & =\mathrm{BOD}_{\mathrm{t}}(\mathrm{mg} / \mathrm{l}) \\
\mathrm{y}, & =\left(\mathrm{y}_{\mathrm{n}+1}-\mathrm{y}_{\mathrm{n}-1}\right) / 2 \Delta \mathrm{t} \\
\mathrm{b} & =-\mathrm{K} \\
\mathrm{a} & =-\mathrm{b} \text { UBOD }
\end{array}
$$

Jika konsentrasi awal senyawa organik sebagai BOD adalah $\mathrm{L}_{0}$ yang dinyatakan sebagai BOD ultimate dan $\mathrm{L}_{\mathrm{t}}$ 
adalah BOD pada saat $\mathrm{t}(\mathrm{mg} / \mathrm{l})$ (Metcalf dan Eddy, 2004) seperti yang ditunjukkan pada Persamaan 7.

$\mathrm{L}_{\mathrm{t}}=\mathrm{L}_{0} \cdot \mathrm{e}^{-\mathrm{K}^{\prime} \mathrm{t}}$

Keterangan:

$\mathrm{L}_{\mathrm{t}}=\mathrm{BOD}$ pada saat $\mathrm{t}(\mathrm{mg} / \mathrm{l})$

$\mathrm{L}_{0}=$ konsentrasi senyawa organik $(\mathrm{mg} / \mathrm{l})$

$\mathrm{K}$ = konstanta dekomposisi bahan organik $\left(\right.$ hari $\left.^{-1}\right)$

$\mathrm{t}=$ waktu (hari)

\section{Perhitungan Konstanta Deoksigenasi} (Kd) dan Laju Deoksigenasi (rD)

Konstanta dekomposisi bahan organik pada perairan sungai berbeda dengan konstanta sekomposisi pada botol BOD karena pertimbangan faktor alamiah sungai (Haider, dkk., 2013). Kedalaman (H) sungai mempengaruhi kehidupan mikroba karena semakin dalam sungai maka semakin rendah suplai oksigen dan sedikit mikroba yang dapat bertahan hidup (Yustiani, dkk., 2018). Nilai Kd diperoleh dari persamaan Hydroscience (1971) (Haider, dkk., 2013) yang disajikan pada Persamaan 8.

$\mathrm{Kd}=0,3 \times\left(\frac{H}{8}\right)^{-0,434}$

Keterangan:

$\mathrm{Kd}=$ konstanta deoksigenasi $\left(\right.$ hari $\left.^{-1}\right)$

$\mathrm{H}=$ kedalaman sungai $(\mathrm{m})$

Laju deoksigenasi mengindikasikan kecepatan reduksi oksigen per hari akibat sekomposisi bahan organik yang larut dalam air. Laju deoksigenasu akibat senyawa organik dapat dinyatakan dengan Persamaan 9 (Hendriarianti dan Karnaningroem, 2015).

$\mathrm{rD}=\mathrm{KdT} \times \mathrm{L}_{\mathrm{t}}=\mathrm{Kd}(1.047)^{\mathrm{T}-20} \times \mathrm{L}_{\mathrm{t}} \ldots$.

Keterangan:

$\mathrm{rD}=$ laju deoksigenasi (mg/l hari)

\section{Perhitungan Konstanta Reoksigenasi (Kr) dan Laju Reoksigenasi (rR)}

Nilai konstanta kecepatan reoksigenasi $(\mathrm{Kr})$ menunjukkan besarnya laju penyerapan oksigen atmosfer ke dalam perairan. Besarnya Kr di perairan tergantung dari kombinasi antara nilai kecepatan (V) dan kedalaman air (H) (Astono, 2010). Nilai konstanta reoksigenasi menggunakan Persamaan 10.

$$
\begin{aligned}
\mathrm{Kr} & =\frac{294\left(D_{L T} \times v\right)^{1 / 2}}{H^{3 / 2}} \\
& =\frac{294\left(\left(1.76 \times 10^{-4} \times(1.037)^{T-20}\right) \times v\right)^{1 / 2}}{H^{3 / 2}} \ldots
\end{aligned}
$$

Keterangan:

$\mathrm{Kr} \quad=$ konstanta reoksigenasi $\left(\right.$ hari $^{-1}$ )

$\mathrm{T}=$ temperature air sungai $\left({ }^{\circ} \mathrm{C}\right)$

$\mathrm{D}_{\mathrm{L}} \mathrm{T} \quad=$ koefisien difusi molekuar oksigen pada temperature $\mathrm{T}^{\circ} \mathrm{C}\left(\mathrm{m}^{2} /\right.$ hari $)$

$\mathrm{v} \quad=$ kecepatan aliran rata-rata (m/detik)

$1,76 \times 10^{-4}=$ koefisien difusi molecular oksigen pada temperature $20^{\circ} \mathrm{C}$

Menurut Keputusan Menteri Negara Lingkungan Hidup Nomor 110 Tahun 2003 tentang Pedoman Penetapan Daya Tampung Beban Pencemaran Air pada Sumber Air, kandungan oksigen di dalam air akan menerima tambahan akibat turbulensi sehingga berlangsung perpindahan oksigen dari udara ke air; proses ini disebut proses reoksigenasi. Kecepatan transfer oksigen dari udara ke air dapat dinyatakan dengan Persamaan 11.

$$
\begin{aligned}
\mathrm{rR} & =\operatorname{KrT} \times \mathrm{D} \\
& =\left(\operatorname{Kr}(1.016)^{\mathrm{T}-20}\right)\left(\mathrm{DO}_{\mathrm{s}}-\mathrm{DO}_{\mathrm{act}}\right) \ldots . .
\end{aligned}
$$

Keterangan:

$\begin{aligned} \mathrm{rR}= & \text { laju reoksigenasi }(\mathrm{mg} / \mathrm{l} \text { hari }) \\ \mathrm{D} & =\text { defisit oksigen terlarut }(\mathrm{mg} / \mathrm{l}) \\ \mathrm{DOs}= & \text { konsentrasi oksigen terlarut } \\ & \text { jenuh }(\mathrm{mg} / \mathrm{l}) \\ \text { DOact }= & \text { konsrentrasi oksigen terlarut air } \\ & \text { sungai }(\mathrm{mg} / \mathrm{l}) \\ \mathrm{H} \quad= & \text { kedalam aliran rata-rata }(\mathrm{m})\end{aligned}$




\section{HASIL DAN PEMBAHASAN}

\section{Kualitas Air Sungai Mayang}

Data hasil analisis kualitas air Sungai Mayang segmen Desa Garahan Krajan sampai Desa Sumberjati disajikan pada Tabel 2. Hasil analisis menunjukkan bahwa nilai parameter Total Suspended Solid (TSS) sebesar 1,36 mg/l, Total Dissolved Solid (TDS) sebesar 199,61 mg/l, Power Hydrogen ( $\mathrm{pH})$ sebesar 7,41, Dissolved Oxygen (DO) sebesar 7,55 mg/l, dan Biochemical Oxygen Demand (BOD) sebesar $0,33 \mathrm{mg} / \mathrm{l}$ memenuhi kriteria mutu air kelas I; sedangkan nilai paramater Chemical Oxygen Demand (COD) masuk ke dalam kriteria mutu air kelas II, yaitu sebesar 48,56 mg/l sebagaimana ketentuan pada Peraturan Pemerintah Nomor 82 Tahun 2001 tentang pengelolaan kualitas air dan pengendalian pencemaran air. Dengan demikian, kualitas air Sungai Mayang berada pada kriteria mutu air kelas II. Kriteria mutu air tersebut didukung dengan nilai COD yang tinggi pada titik MYG02 mutu air yang sama dengan kegunaan tersebut.

\section{Debit Sungai Mayang}

Data hasil pengukuran dan perhitungan debit Sungai Mayang Segmen Desa Garahan Krajan sampai Desa Sumberjati, Kecamatan Silo, Kabupaten Jember yang merupakan Sungai Mayang bagian hulu ditunjukkan pada Tabel 3 .

Pada Tabel 3 dapat dilihat bahwa nilai debit pada setiap titik memiliki nilai yang berbeda. Kecepatan aliran tertinggi berada pada titik MYG01 dan titik MYG03 memiliki kecepatan aliran terendah. Tinggi rendahnya nilai debit dipengaruhi oleh kecepatan aliran dan kedalaman atau luas permukaan dari setiap pias pada masingmasing titik, karena dalam mencari debit aliran, luas permukaan berbanding lurus dengan kecepatan aliran dan debit aliran. Keadaan sungai pun berpengaruh dalam menentukan nilai debit alirannya. Seperti halnya titik MYG01 yang dangkal dibandingkan titik yg lain tetapi memiliki

Tabel 2. Kualitas Air Sungai Mayang

\begin{tabular}{|c|c|c|c|c|c|c|c|c|c|c|}
\hline \multirow{2}{*}{ Parameter } & \multirow{2}{*}{ Satuan } & \multicolumn{4}{|c|}{ Titik Pantau } & \multirow{2}{*}{$\begin{array}{l}\text { Rata- } \\
\text { rata }\end{array}$} & \multicolumn{4}{|c|}{ Kriteria mutu air } \\
\hline & & MYG01 & MYG02 & MYG03 & MYG04 & & I & II & III & IV \\
\hline Temperatur & $\mathrm{C}$ & 22,40 & 22,56 & 23,89 & 24,11 & 23,24 & - & - & - & - \\
\hline Kekeruhan & NTU & 1,71 & 1,56 & 2,67 & 2,27 & 2,05 & - & - & - & - \\
\hline TSS & $\mathrm{mg} / \mathrm{l}$ & 1,11 & 2,11 & 0,89 & 1,33 & 1,36 & 50 & 50 & 400 & 400 \\
\hline TDS & $\mathrm{mg} / \mathrm{l}$ & 209,56 & 225,78 & 186,44 & 176,67 & 199,61 & 1000 & 1000 & 1000 & 2000 \\
\hline $\mathrm{pH}$ & & 7,46 & 7,67 & 7,9 & 6,6 & 7,41 & $6-9$ & $6-9$ & $6-9$ & $5-9$ \\
\hline DO & $\mathrm{mg} / \mathrm{l}$ & 7,4 & 7,44 & 7,81 & 7,54 & 7,55 & 6 & 4 & 3 & 0 \\
\hline BOD & $\mathrm{mg} / \mathrm{l}$ & 0,26 & 0,47 & 0,26 & 0,32 & 0,33 & 2 & 3 & 6 & 12 \\
\hline COD & $\mathrm{mg} / \mathrm{l}$ & 28 & 34,22 & 80,78 & 51,22 & 48,56 & 10 & 25 & 50 & 100 \\
\hline
\end{tabular}

Sumber: Peraturan Pemerintah Nomor 82 Tahun 2001

karena adanya limbah domestik dari pemukiman penduduk yang dibuang langsung ke Sungai Mayang.

Berdasarkan mutu air kelas II maka Sungai Mayang sebagaimana peruntukannya dapat digunakan untuk prasarana atau sarana rekreasi air, pembudidayaan ikan air tawar, peternakan, air untuk mengairi pertanaman, dan atau peruntukan lain yang mempersyaratkan kecepatan aliran yang lebih besar, di setiap aliran terdapat banyak batuan yang dapat mempengaruhi kecepatan aliran dan pengukuran kedalaman sungai. Selain itu dalam menentukan nilai debit aliran sungai juga dapat dipengaruhi oleh adanya rembesan air sungai ke dalam tanah dan adanya sedimentasi yang dapat menjadi salah satu faktor rendahnya nilai debit. 
Tabel 3. Debit Sungai Mayang

\begin{tabular}{ccccc}
\hline \multirow{2}{*}{ Titik } & \multicolumn{4}{c}{ Debit $\left(\mathrm{m}^{3} /\right.$ detik) } \\
\cline { 2 - 4 } Pantau & \multicolumn{3}{c}{ Ulangan } & Rata-rata \\
\cline { 2 - 4 } & 1 & 2 & 3 & 0,67 \\
MYG01 & 0,66 & 0,65 & 0,69 & 0,62 \\
MYG02 & 0,63 & 0,59 & 0,65 & 0,25 \\
MYG03 & 0,27 & 0,27 & 0,20 & 0,25 \\
MYG04 & 0,19 & 0,34 & 0,38 & 0,30 \\
\hline \multicolumn{4}{c}{ Rata-rata } & 0,46 \\
\hline
\end{tabular}

Menurut Welch dan Lindel (1980), terdapat lima kategori arus yaitu arus yang sangat lambat (kurang dari $0,10 \mathrm{~m}^{3} /$ detik), lambat $\left(0,10-0,25 \mathrm{~m}^{3} /\right.$ detik $)$, sedang $(0,25$ $0,50 \mathrm{~m}^{3} /$ detik), cepat $\left(0,50-1,00 \mathrm{~m}^{3} /\right.$ detik), dan sangat cepat (lebih dari $1 \mathrm{~m}^{3} /$ detik). Berdasarkan Tabel 3, Sungai Mayang termasuk kategori arus cepat yaitu berkisar 0,50-1,00 $\mathrm{m}^{3} /$ detik. Berdasarkan Tabel 2, Sungai Mayang segmen Desa Garahan Krajan sampai Desa Sumberjati termasuk kategori arus sedang yaitu 0,25-0,50 $\mathrm{m}^{3} /$ detik.

\section{Laju Deoksigenasi dan Laju Reoksigenasi}

Menurut Ayudina, (2017), semakin dalam kedalaman suatu sungai, semakin sedikit kandungan oksigennya dan sedikit juga jumlah mikroorgansime yang dapat hidup di perairan tersebut, sehingga mempengaruhi nilai konstanta deoksigenasi (Kd). Hasil perhitungan laju deoksigenasi (rD) dan laju reoksigenasi (rR) disajikan pada Tabel 4.

Tabel 4. Data Perhitungan Laju Deoksigenasi (rD) dan Laju Reoksigenasi (rR) Sungai Mayang Segmen Desa Garahan Krajan sampai Desa Sumberjati

\begin{tabular}{ccccccccc}
\hline \multirow{2}{*}{ Titik Pantau } & $\mathrm{V}$ & $\mathrm{H}$ & $\mathrm{Kd}$ & $\mathrm{Kr}$ & $\mathrm{Lt}$ & $\mathrm{D}$ & $\mathrm{rD}$ & $\mathrm{rR}$ \\
\cline { 2 - 9 } & $\mathrm{m}^{2} /$ detik $^{-1}$ & $\mathrm{~m}$ & hari $^{-1}$ & hari $^{-1}$ & $\mathrm{mg} / \mathrm{l}$ & $\mathrm{mg} / \mathrm{l}$ & $\mathrm{mg} / \mathrm{l}$ hari & $\mathrm{mg} / \mathrm{l} \mathrm{hari}$ \\
\hline MYG01 & 0,23 & 0,22 & 1,32 & 14,77 & 0,003 & 13,38 & 0,005 & 13,38 \\
MYG02 & 0,19 & 0,38 & 1,08 & 6,50 & 0,003 & 0,84 & 0,004 & 5,72 \\
MYG03 & 0,08 & 0,35 & 1,09 & 4,44 & 0,000 & 0,30 & 0,000 & 1,42 \\
MYG04 & 0,11 & 0,33 & 1,07 & 4,99 & 0,000 & 0,29 & 0,000 & 1,42 \\
\hline Rata-rata & 0,15 & 0,32 & 1,14 & 7,68 & 0,002 & 3,70 & 0,002 & 5,49 \\
\hline
\end{tabular}

Nilai laju deoksigenasi (rD) tertinggi pada titik lokasi MYG01 dipengaruhi oleh Kd yang memiliki nilai tertinggi yaitu 1,32 $\mathrm{mg} / \mathrm{l} / \mathrm{hari}$. Nilai $\mathrm{rD}$ terendah pada titik lokasi MYG03, tetapi Kd yang memiliki nilai terendah berada pada titik lokasi MYG04, yaitu $1,07 \mathrm{mg} / \mathrm{l} / \mathrm{hari}$. Hal tersebut dapat disebabkan karena profil dasar sungai yang tidak rata dan dipenuhi bebatuan serta kerikil, sehingga terjadi turbulensi dan mempercepat proses penambahan oksigen (reoksigenasi). Semakin tinggi rD menujukkan bahwa oksigen terlarut (DO) yang terkandung dalam perairan semakin menurun, sedangkan DO yang terkandung dalam perairan sungai menentukan kesehatan sungai tersebut.

Laju reoksigenasi (rR) menunjukkan kecepatan berdifusinya gas oksigen ke badan air akibat faktor hidrolik. Secara teoritis, laju reoksigenasi dipengaruhi oleh konstanta reoksigenasi terhadap suhu (KrT) yang menunjukkan kecepatan pengambilan oksigen oleh sungai dari atmosfir dan defisit oksigen terlarut (D). Konstanta reoksigenasi (Kr) merupakan fungsi kecepatan aliran sungai (V) dan kedalaman (H). Semakin besar kecepatan aliran dan semakin dangkalnya sungai, konstanta reoksigenasi semakin besar, begitu pun sebaliknya (Astono, 2010). Nilai Kr tertinggi pada titik MYG01 dipengaruhi kecepatan aliran yang tinggi dan rata-rata kedalaman yang rendah. Sedangkan $\mathrm{Kr}$ terendah berada pada titik MYG03 dipengaruhi oleh kondisi sungai yang lebih dalam dan tenang. Perbandingan antara nilai kecepatan yang rendah dan profil sungai yang dalam menyebabkan nilai konstanta reoksigenasi menurun. Semakin besar $\mathrm{Kr}$, semakin banyak oksigen yang 
masuk ke dalam air sungai dan menyebabkan konsentrasi oksigen terlarut (DO) meningkat serta menghindari terjadinya defisit oksigen yang berlebihan.

\section{KESIMPULAN DAN SARAN}

\section{Kesimpulan}

Dari hasil penelitian Sungai Mayang segmen Desa Garahan Krajan sampai Desa Sumberjati memiliki rata-rata laju deoksigenasi (rD) sebesar 0,002 mg/l.hari dan laju reoksigenasi (rR) sebesar 5,49 $\mathrm{mg} / \mathrm{l}$.hari. Nilai rD yang lebih kecil dari nilai $\mathrm{Rr}$ menunjukkan bahwa penambahan oksigen terlarut lebih besar dibandingkan pengurangan oksigen terlarut di dalam perairan sehingga purifikasi alami sungai dapat berlangsung dengan baik.

\section{Saran}

Dari hasil penelitian ini perlu dilakukan penelitian lanjutan yaitu menghitung daya tampung Sungai Mayang segmen Desa Garahan Krajan sampai Desa Sumberjati agar dapat diketahui kemampuan daya tampung sungai tersebut dalam menerima beban pencemaran.

\section{UCAPAN TERIMA KASIH}

Terima kasih kami sampaikan kepada DIPA Universitas Jember Tahun 2019 yang telah memberikan kesempatan dan support kepada tim peneliti dalam melaksanakan penelitian ini.

\section{DAFTAR REFERENSI}

Arbie, R.R., Nugraha, W.D., \& Sudarsono. (2015). Studi Kemampuan Self Purification pada Sungai Progo Ditinjau dari Parameter Organik DO dan BOD (Point Source: Limbah Sentra Tahu Tuksono, Kecamatan Sentolo, Kabupaten Kulon Progo, Provinsi D.I. Yogyakarta). Jurnal Teknik Lingkungan, 4(3), 1-15.
Astono, W. (2010). Penetapan Nilai Konstanta Dekomposisi Organik (Kd) dan Nilai Konstanta Reoksigenasi (Ka) pada Sungai Ciliwung Hulu Hilir. Jurnal EKOSAINS, 2(1), 40-45.

Ayudina, A. (2017). Penentuan Nilai Koefisien Laju Deoksigenasi Sungai Citarum Segmen Tengah. Jurusan Teknik Lingkungan, Fakultas Teknik, Universitas Pasundan.

Badan Standardisasi Nasional. (2008). Standar Nasional Indonesia Nomor 06-6989.57, Air dan Air Limbah Bagian 57: Metoda Pengambilan Contoh Air Permukaan. Jakarta.

Badan Standardisasi Nasional. (2015). Standar Nasional Indonesia 8066, Tata Cara Pengukuran Debit Aliran Sungai dan Saluran Terbuka Menggunakan Alat Ukur Arus dan Pelampung. Jakarta.

Dinas Kebersihan dan Lingkungan Hidup Kabupaten Jember. (2007). Status Lingkungan Hidup Daerah Kabupaten Jember Tahun 2007. Dinas Kebersihan dan Lingkungan Hidup. Jember.

Haider, H., Ali, W. \& Haydar, S. (2013). A Riview of Dissolved Oxygen and Biochemical Oxygen Demand models for Large rivers. Pakistan Journal of Engineering and Applied Science, 12, 127-142.

Hendriarianti, E. \& Karnaningroem, N. (2015). Deoxygenation rate of carbon in upstream brantas river in the city of Malang. Journal of Applied Environmental and Biological Sciences, 5(12), 36-41.

Kahirun, Siwi L.O., Surya R.A., Erif L.O. M., Yasin, A., \& Ifrianty. (2019). Indikator Kualitas Air Sungai Dengan Menggunakan Makroinvertebrata di 
Sungai Wanggu. Ecogreen, 5(1), 6367.

Kementrian Lingkungan Hidup. (2001). Pemerintah Republik Indonesia Nomor 82 tentang Pengelolaan Kualitas Air dan Pengendalian Pencemaran Air. Kementrian Lingkungan Hidup. Jakarta.

Kementrian Lingkungan Hidup. (2003). Keputusan Menteri Negara Lingkungan Hidup Nomor 110 tentang Pedoman Penetapan Daya Tampung Beban Pencemaran Air pada Sumber Air Kementrian Lingkungan Hidup. Jakarta.

Metcalf \& Eddy. (2004). Wastewater Engineering, $4^{\text {th }}$ edition. New York: McGraw-Hill.
Rahayu, S., Widodo, R.H., Noordwijk, M.V., Suryadi, I. \& Verbist, B. (2009). Monitoring Air di Daerah Alirang Sungai. Bogor: World Agroforestry Centre.

Triatmodjo, B. (2013). Hidrologi Terapan. $3^{\text {rd }} e d$. Yogyakarta: Beta Offset.

Welch, E. B \& T. Lindell. (1980). Ecological Effect of Waste Water. London: Cambridge University Press.

Yustiani, Y.M., Wahyuni, S. \& Alfian, M.R. (2018). Investigation on the Deoxygenation rate of water of Cimanuk River Indramayu Indonesia. Rasayan J. Chem, 11(2), 475- 481. 